\title{
ABUSO SEXUAL INFANTIL: O POSICIONAMENTO DE DOCENTES QUANTO À PROBLEMÁTICA FRENTE AOS SEUS ALUNOS
}

\section{ENTREVISTA}

GONÇALVES, Natamy de Almeida ${ }^{1}$, DIAS, Camila Santos²

GONÇALVES, Natamy de Almeida. DIAS, Camila Santos. Abuso sexual infantil: o posicionamento de docentes quanto à problemática frente aos seus alunos. Revista Científica Multidisciplinar Núcleo do Conhecimento. Ano 06, Ed. 09, Vol. 01, pp. 209-250. Setembro de 2021. ISSN: 2448-0959, Link de acesso: https://www.nucleodoconhecimento.com.br/psicologia/posicionamento-de-docentes, DOI: 10.32749/nucleodoconhecimento.com.br/psicologia/posicionamento-dedocentes

\section{RESUMO}

O abuso sexual é um fenômeno social que necessita de uma atenção refinada por se tratar de um assunto complexo que gera sofrimento a muitas crianças, adolescentes e famílias. Considerando que a escola é um contexto importante para a criança e o adolescente, e que está envolvida no processo de formação de identidade e aspectos que perpassam pelo desenvolvimento biopsicossocial do aluno, tal instituição tem o importante papel de colaborar para a proteção deste. A partir de tais considerações, esta pesquisa apresenta a seguinte questão norteadora: os professores têm o conhecimento necessário sobre o abuso sexual e suas responsabilidades quanto ao tema no contexto escolar de modo a estarem preparados para identificar, prevenir ou conduzir famílias às medidas necessárias? Assim, esta pesquisa teve como objetivo conhecer e discutir sobre o posicionamento

\footnotetext{
${ }^{1}$ Pós-graduada em Neuropsicologia pela Faculdade de Tecnologia, Ciências e Educação - FATECE, pós-graduada em Psicologia Organizacional e do Trabalho na Fundação Hermínio Ometto e graduada em Psicologia pela mesma instituição.

${ }^{2}$ Mestre em Psicologia como Ciência e Profissão (PUCCamp), Especialista em Educação e Psicopedagogia (PUCCamp), Especialista em Neuropsicologia (Instituto Hospital Israelita Albert Einstein), Graduada em Psicologia (Fundação Hermínio Ometto - FHO)

RC: 96446

Disponível em:

https://www.nucleodoconhecimento.com.br/psicologia/posicionamento-de-docentes
} 
de professores com relação à prevenção, suspeita e identificação do abuso sexual infantil, no contexto escolar. Então, após a aprovação do Comitê de Ética e Mérito Científico da Fundação Hermínio Ometto, via Plataforma Brasil e da emissão do Parecer Consubstanciado do CEP de №1.511.605, foi feita uma pesquisa qualitativa, aplicada e empírica, com técnica de levantamento e, para a análise dos dados coletados foram utilizadas a técnicas de análise de conteúdo e de análise temática, aplicando a Entrevista como um instrumento de coleta de dados, analisando de forma crítica a realidade apresentada e contribuindo cientificamente para o desenvolvimento de novas visões sobre a presente problemática. Os resultados deste estudo mostraram que os professores têm pouca apropriação do que é o abuso sexual infantil e sobre suas responsabilidades quanto a tal violência. Além disso, sentem-se despreparados para o enfrentamento do problema, não possuem formação adequada para tal e não têm respaldo de formação continuada que thes proporcionem preparo para isto. Concluiu-se, então, que é necessário que haja a capacitação dos professores, e que o psicólogo escolar/educacional pode fazer intervenções significativas com toda a equipe escolar, como também trabalhar com a comunidade, dando orientações a pais e familiares para que eles possam corroborar para o combate a tão repudiável crime.

Palavras-Chave: Abuso Sexual Infantil, Violação Sexual Infantil, Professores.

\section{INTRODUÇÃO}

O abuso sexual infantil é um problema que já afetou milhares de crianças e adolescentes em todo o mundo em diversos períodos da história. Tal violência persiste nos dias atuais e continua ganhando espaço, já que, na maioria dos casos, o agressor faz parte da família da vítima ou é muito próximo dela. Esse é um dos fatores que atrapalham não apenas na prevenção e na identificação do abuso sexual, como também na denúncia do abusador e, como mostram Aded et al. (2006), acredita-se que o número de casos é maior do que o de notificações. 
A escola é um contexto importante para a criança, já que está envolvida no processo de formação de identidade e aspectos que perpassam pelo desenvolvimento biopsicossocial do aluno (SERAFIM et al., 2011). Além disso, tal instituição tem o importante papel de colaborar para a proteção da criança e do adolescente de acordo com o Estatuto da Criança e do Adolescente (BRASIL, 1990). Entretanto, como apontam Inoue e Ristum (2008), muitos profissionais têm se distanciado desta responsabilidade em sua prática. As autoras denotam ainda que o papel do docente com relação a este cuidado é de grande importância, já que professores podem ser agentes fundamentais para o processo de prevenção, identificação ou encaminhamento de possíveis alunos vítimas de abuso sexual infantil.

A partir de tais considerações, esta pesquisa apresenta a seguinte questão norteadora: os professores têm o conhecimento necessário sobre o abuso sexual e suas responsabilidades quanto ao tema no contexto escolar de modo a estarem preparados para identificar, prevenir ou conduzir famílias às medidas necessárias? Assim, esta pesquisa teve como objetivo conhecer e discutir sobre o posicionamento de professores com relação à prevenção, suspeita e identificação do abuso sexual infantil, no contexto escolar.

Considera-se, então, que essa investigação é socialmente relevante, e que o tema é bastante discutido por diferentes autores, como Ynoue e Ristum (2008), Araújo (2002) e Azambuja (2006), por exemplo, que falam sobre as características comuns entre agressores, locais e vítimas do abuso; problematizam sobre $o$ ato de denunciar ou não o agressor; pontuam diferentes tipos de serviços de atendimento à vítima e à sua família; e até abordam sobre como a escola e seus profissionais se implicam diante da problemática, entre outras discussões. Porém, pouco se pesquisa acerca da realidade do conhecimento dos docentes perante o abuso sexual infantil, não discutindo sobre sua formação acadêmica e/ou continuada com relação ao tema, ou possíveis suportes que os governos federal, estadual ou municipal oferecem a esses docentes, pensando, além da aquisição do conhecimento, a preparação para a prática desses profissionais frente à prevenção, identificação e direcionamento do processo após uma possível constatação de alunos vítimas de abuso sexual. Sendo 
assim, entende-se que é cientificamente relevante a feitura desta pesquisa. Por conseguinte, esta pesquisa visou conhecer e discutir sobre o posicionamento de professores com relação à suspeita e identificação do abuso sexual infantil frente a seus alunos, bem como a posição desses profissionais quanto a prevenção no contexto escolar.

\section{FUNDAMENTAÇÃO TEÓRICA}

Segundo o Ministério da Saúde, o abuso sexual trata-se de todo jogo ou ato sexual cujo agressor está em estágio de desenvolvimento psicossexual mais adiantado que o da vítima, sendo ela criança ou adolescente, sob intenção de estimulá-la sexualmente ou de se utilizar dela para a obtenção do prazer sexual. Ocorre por meio de práticas eróticas e sexuais que são impostas pela violência física, ameaças ou até a indução de sua vontade. Caracteriza-se por atos em que não ocorre contato físico, como no caso do voyeurismo (observação de uma pessoa nua, no ato de se despir ou realizando atos sexuais) e do exibicionismo (exibição da própria nudez), como também por ações de contato sexual com ou sem penetração. Além disso, engloba a exploração sexual (visando lucros), que é o caso da pornografia e a prostituição (BRASIL, 2002, p. 13).

Apesar das leis atualmente serem favoráveis à peleja contra a violência sexual infantil, há a falta de coerência destas com muitas práticas de pessoas que têm em sua profissão a função de trabalhar a favor de crianças e adolescentes, como a equipe escolar, por exemplo. A atuação de muitos profissionais da área da educação ainda está distante da proposta do ECA, pois muitos que se deparam com evidências de maus tratos não se encontram preparados para uma atuação condizente com o Estatuto da Criança e do Adolescente.

A escola é uma instituição que, dentre as suas outras atribuições, também deve ser comprometida em garantir os direitos das crianças e adolescentes, e a adesão dos educadores é primordial para que a teoria desses direitos seja refletida na prática. "A atuação do professor na identificação e denúncia da violência sexual é fundamental, 
principalmente nas primeiras séries, quando os educadores permanecem cerca de quatro horas diárias com as crianças" (INOUE; RISTUM, 2008, p.15).

Diante da gravidade da problemática, a escola tem um papel importante e é parte de uma rede fundamental não apenas para o processo de formação de identidade e socialização do aluno, mas também para a proteção da criança (INOUE; RISTUM, 2008). Para isso, é imprescindível que os profissionais estejam capacitados e dispostos a fazer com que a escola cumpra este papel. Assim, é de grande pertinência se pensar nos aspectos que envolvem $o$ atual conhecimento $e$ posicionamento de docentes quanto ao abuso sexual.

Vagostello et al. (2003) realizaram um estudo em escolas públicas do Estado de São Paulo, visando verificar sobre a capacidade de reconhecimento de alunos vítimas de violência doméstica, e como se dá o encaminhamento dessas situações no contexto escolar. O resultado desta pesquisa apontou que, apesar de as escolas serem capazes de identificar os casos de crianças violentadas dentre seus alunos, há ainda a necessidade de se abordar melhor sobre o assunto, já que a equipe escolar apresentou dificuldade para tal; viu-se ainda que muitos casos acabam por ser negados, ocultados ou tratados equivocadamente.

Isto porque, como bem denota Williams (2002), em pleno século $X X I$, a violência sexual ainda é considerada como um tabu, e quando a integridade física ou sexual da vítima é afetada de modo violento, muitas vezes a própria vítima é estigmatizada e, frequentemente apresenta sentimento de culpa ou vergonha, o que pode levar ao isolamento social. Este, dentre outros, é um dos motivos para a não denúncia por parte de pessoas que fazem ou não parte da família da vítima, e até mesmo por parte da escola. Como esses casos podem envolver riscos como ameaças do agressor, ou complicações, como um abalo na estrutura familiar quando este faz parte da família, é comum que terceiros como a escola, não queiram se envolver, ou prefiram se acomodar com o silêncio do aluno agredido sexualmente, por se tratar de um assunto delicado, sério, e que exige um preparo para lidar com esse tipo de situação. 
Para Cardoso e Menezes (2009), o Estado tem o dever de prevenir abuso sexual infantil com medidas como o investimento de verbas em programas de capacitação e conscientização de profissionais estatais, e da sociedade de forma geral, fazendo desta, uma sociedade mais segura, de maneira que respeite e proteja crianças e adolescentes, oferecendo também lazer em lugares que estes possam manter-se em segurança como, por exemplo, em escolas, creches, e abrigos, sendo acompanhados por profissionais capacitados. A educação deve ser privilegiada e defendida pelos defensores dos direitos humanos, necessitando de atenção de forma imediata e munida de responsabilidade por parte do Estado. Também, em relação às crianças e adolescentes em condição peculiar de desenvolvimento, atua com um papel decisivo em prol da prevenção e detenção da violência sexual infantil.

Os autores frisam a importância de a qualificação e sensibilização de agentes estatais acerca do abuso não ser somente direcionados a uma ou outra área específica, devem-se dar de forma irrestrita e constante, permeando o trabalho tanto de profissionais envolvidos diretamente com a assistência às crianças e adolescentes vítimas do abuso sexual, como também dos que têm contatos eventuais como, por exemplo, funcionários administrativos. Pensando no contexto escolar, esta preparação pode ser feita com todos os funcionários da instituição (CARDOSO; MENEZES, 2009).

Longo (2006) aponta a importância do falar sobre a violência sexual com as crianças, pois esse é um meio de protegê-las das manipulações do abusador. Com a aquisição de informações acerca do assunto, a criança pode conhecer melhor o seu corpo, sobre como e por quem ele pode ser tocado, e essa pode ser uma medida de prevenção pois, em geral, o abusador tem a tendência de se aproximar de crianças por serem mais vulneráveis por falta de informações ou de estrutura emocional.

A autora indica que a maior parte das vítimas do abuso não relata o acontecido, pois teme que façam algo contra ela, e porque tem medo de desfazer a família por conta da situação. $O$ que pode ser pior do que o abuso em si é a vítima pensar ser a 
responsável pela destruição da própria família. Outras razões para este silêncio podem ser: ameaças por parte do abusador, entender o abuso como um aspecto/acontecimento cotidiano/comum ou nem se dar conta de que ele está acontecendo, a distorção da realidade provocada pelo violentador e medo deste, como também de não acreditarem nela, e fatores como culpa, vergonha, embaraço, entre outros (LONGO, 2006).

Assim, a escola enquanto uma instituição que ocupa um lugar de atenção à criança e ao adolescente precisa estar preparada para a prevenção que Longo (2006) propõe, ou seja, que possa se dar por meio de criação de programas para trabalhar o tema, a identificação precoce de crianças em "situação de risco", capacidade de reconhecer os indícios da violência sexual nos alunos etc. Para isso, "treinar" o olhar e a capacidade de escuta dos educadores para esta percepção, saber como notificar e encaminhar para as autoridades competentes, para cuidados médicos, psicológicos e acompanhar essa vítima integralmente, trabalhando para que isto não se repita; acompanhar também o abusador para que este seja responsabilizado e permitir que este possa ter uma ajuda psicológica. Vale destacar a importância de se desconstruir medos e preconceitos que podem existir por parte desses educadores, para que estes não hesitem em tomar atitudes em favor de seus alunos nesse sentido.

Brino e Williams (2003b, p.1) realizaram um estudo na perspectiva da prevenção, com o objetivo de "[...] avaliar a eficácia de uma intervenção com educadoras no sentido de capacitá-las a atuarem com casos de abuso sexual". Os dados obtidos revelam que muitas professoras teriam como atitude encaminhar os casos de abuso sexual à direção da escola e, nas palavras dos autores do estudo, "esse fato chama a atenção para a importância de se envolver a administração escolar em projetos de capacitação semelhantes ao presente estudo" (BRINO; WILLIAMS, 2003b, p.8). Outro fato que demonstra essa necessidade é que há uma hierarquia administrativa na escola, que parece ser respeitada principalmente quando se trata de assuntos delicados como o abuso sexual infantil. 
Assim, tanto os professores, quanto a direção da escola, precisam ter conhecimento acerca dos direitos da criança, pois ter uma consciência clara sobre eles permite uma maior sensibilidade para o reconhecimento dos casos de violência sexual. "Mas apenas conhecer não basta, é preciso saber denunciar, lidar com a criança que foi abusada, dando-lhe suporte e apoio e encaminhá-la para tratamentos especializados" (BRINO; WILLIAMS, 2003b, p.2).

O site da UNICEF[3] informa alguns modos de fazer denúncias, e uma delas é entrando em contato com o Conselho Tutelar, já que os conselheiros têm o papel de zelar pelo cumprimento dos direitos da criança e do adolescente. Segundo o site da instituição, "a eles cabe receber a notificação e analisar a procedência de cada caso, visitando as famílias. Se for confirmado o fato, o Conselho deve levar a situação ao conhecimento do Ministério Público". O ECA prevê que

Art. 70-B. As entidades, públicas e privadas, que atuem nas áreas a que se refere 0 art. 71, dentre outras, devem contar, em seus quadros, com pessoas capacitadas a reconhecer e comunicar ao Conselho Tutelar suspeitas ou casos de maus-tratos praticados contra crianças e adolescentes (BRASIL, 1990).

Deste modo, a lei prevê que os profissionais das áreas da informação, cultura, lazer, diversões, entre outros aspectos citados no art. 71, precisam estar capacitados para fazerem denúncias ao Conselho Tutelar frente à violação do direito da criança ou do adolescente, bem como em casos de Abuso Sexual (BRASIL, 1990).

Sendo assim, o Conselho Tutelar é um órgão propício para o recebimento de denúncias de violências, dentre elas a sexual. Outra proposta para a denúncia apresentada pelo site da UNICEF é contatar as Varas da Infância e da Juventude, caso o município não possua Conselho Tutelar. Outros órgãos que também podem receber a denúncia são as Delegacias de Proteção à Criança e ao adolescente, como também as Delegacias da Mulher. Há também um aplicativo para tablets e smartphones chamado Proteja Brasil, que mostra a localização e os telefones da instituição especializada mais próxima de onde o denunciante estiver; em caso de 
dúvidas sobre o tipo de violência, o aplicativo pode auxiliar com as informações necessárias.

Ainda, outro meio de se fazer uma denúncia pode ser via Disque 100 - Direitos Humanos, canal em que "as denúncias poderão ser anônimas ou, quando solicitado pelo denunciante, é garantido o sigilo da fonte das informações" (BRASIL, s/d). Então, caso haja receio por parte das pessoas quanto ao envolvimento nos casos de violação de direitos, como no caso de Abuso Sexual Infantil, qualquer pessoa pode fazer a denúncia sem que seja identificada, inclusive os próprios membros da equipe escolar. O importante é que não se deixe de denunciar, já que a omissão é um ato tão grave quanto o próprio ato de violência. O ECA, em um Parágrafo único do art. 70-B, deixa claro que

São igualmente responsáveis pela comunicação de que trata este artigo, as pessoas encarregadas, por razão de cargo, função, ofício, ministério, profissão ou ocupação, do cuidado, assistência ou guarda de crianças e adolescentes, punível, na forma deste Estatuto, o injustificado retardamento ou omissão, culposos ou dolosos (BRASIL, 1990).

Assim, fica evidente a responsabilidade e missão de pessoas que de alguma forma estão envolvidas na vida da criança e do adolescente, de denunciar a violação dos direitos destes, inclusive de delatar um ato tão grave quanto o abuso sexual. Dentre as pessoas que carregam esta obrigação, os educadores são as que têm um papel importantíssimo na vida das crianças, portanto, é imprescindível que estes estejam implicados na denunciação e combate do abuso sexual infantil.

Com base nos autores descritos, pôde-se perceber a grande relevância de se fazer estudos voltados à área do abuso sexual infantil, já que, como mencionado, é um fenômeno grave, complexo, e que traz sofrimento de diferentes maneiras a muitas crianças e adolescentes em todo o mundo. Pensar em medidas que combatem esse mal é de grande responsabilidade de profissionais de diferentes áreas. Assim, se questionará neste trabalho acerca do envolvimento do professor com a problemática, sem desconsiderar a preparação que o psicólogo escolar e educacional deve ter para trabalhar com 0 processo de orientação desses 
educadores que, como sugere Martins (2003), deve ser um agente de mudanças, atuando como quem centraliza reflexões e conscientiza a respeito dos papéis dos vários grupos que compõe a instituição.

\section{METODOLOGIA}

A presente pesquisa fora realizada durante em 2016 e é caracterizada como uma pesquisa de natureza aplicada, abordagem qualitativa, exploratória, considerando seus objetivos, cujo procedimento técnico empregado foi o de levantamento (GERHARDT; SILVEIRA, 2009).

\subsection{PARTICIPANTES}

Foram participantes voluntários desta pesquisa quatro professores que atuavam em uma escola pública de um município do interior do Estado de São Paulo, lecionando para alunos do Ensino Fundamental. O quadro 01 a seguir, para o conhecimento do leitor, apresenta o nome fictício de cada participante, o sexo, a idade, o tempo de formação de cada um deles, bem como o tempo de experiência na área e o tempo de experiência na escola em que foram realizadas as entrevistas.

Quadro 01 - Nome fictício dos participantes, sexo, idade, tempo de formação, de experiência na área e de experiência nesta escola.

\begin{tabular}{|l|l|l|l|l|l|}
\hline Participante & Sexo & Idade & Tempo de & Tempo de & $\begin{array}{l}\text { Tempo } \\
\text { experiência nesta } \\
\text { escola }\end{array}$ \\
\hline Maria & Feminino & 44 & 14 anos & 11 anos & 4 anos \\
\hline Noemi & Feminino & $\begin{array}{l}\text { anos } \\
\text { anomação }\end{array}$ & $\begin{array}{l}\text { Experiência } \\
\text { na área }\end{array}$ & \\
\hline Gleice & Feminino & 49 & 16 anos & 20 anos & 4 anos \\
\hline
\end{tabular}




\begin{tabular}{|l|l|l|l|l|l|}
\hline Pedro & Masculino & $\begin{array}{l}\text { anos } \\
26\end{array}$ & 4 anos & 5 anos & 11 meses \\
anos & & & \\
\hline
\end{tabular}

Fonte: elaborado pelas autoras.

Os participantes foram convidados a participar desta pesquisa por conveniência. Gil (2008) afirma que a escolha dos voluntários por conveniência acontece pelo acesso que o pesquisador tem, permitindo que a amostra represente o universo.

\subsection{INSTRUMENTOS E MATERIAIS UTILIZADOS}

Os dados foram coletados por meio de um roteiro de entrevista semiestruturado, elaborado pelas pesquisadoras deste trabalho, cujas perguntas principais foram concernentes ao objetivo da pesquisa e puderam ser complementadas com outras questões de acordo com as circunstâncias do momento da entrevista. Com consentimento das participantes, fora utilizado um gravado de áudio para favorecer a transcrição e fidedignidade dos dados coletados. Também foi utilizado um Termo de Consentimento Livre e Esclarecido (TCLE), que documenta o consentimento do participante para participar da pesquisa. Outro material indispensável foi a Declaração de Autorização da Instituição onde a pesquisa foi realizada, que registra a permissão do uso de suas instalações bem como a realização da entrevista com pessoas integrantes dela.

\subsection{PROCEDIMENTOS DE COLETA DE DADOS}

A pesquisadora entrou em contato com a diretora responsável pela escola em que lecionam os professores que participaram desta pesquisa, para que assinasse $u$ a Declaração de Autorização da Instituição permitindo a coleta de dados na escola. Dando seguimento ao procedimento de coleta de dados, o projeto desta pesquisa foi submetido à apreciação e avaliação do Comitê de Ética e Mérito Científico da Fundação Hermínio Ometto, via Plataforma Brasil. No dia 20 de abril de 2016 a 
realização desta pesquisa foi aprovada pelo referido Comitê de Ética, a partir da emissão do Parecer Consubstanciado do CEP de ㄲo1.511.605. Após, e tão somente após a aprovação do referido comitê, a pesquisadora teve acesso aos professores voluntários que foram indicados pela coordenadora da escola, já que esta possuía conhecimento sobre a disponibilidade de horário dos professores. Todas as entrevistas ocorreram de acordo com a disponibilidade de horário de cada participante.

\subsection{PROCEDIMENTO PARA ANÁLISE DOS RESULTADOS}

Para esta pesquisa, os dados foram analisados com base na técnica de Análise de Conteúdo. Esta técnica possui duas funções: uma se refere à verificação de hipóteses, podendo encontrar respostas para as questões formuladas, confirmando ou não as afirmações feitas previamente; outra é descobrir o que está por trás dos conteúdos manifestados, olhando não apenas as aparências do que está sendo comunicado, mas também para conteúdos latentes. Essas duas funções podem complementar-se (MINAYO, 2001).

Dentre as várias modalidades de Análise de Conteúdo, destaca-se: Análise Lexical, Análise de Expressão, Análise de Relações, Análise Temática e Análise de Enunciação. Nesta pesquisa, foi feita uma Análise Temática, que trabalha com noção de tema e é ligada a uma afirmação com relação ao assunto, e comporta um feixe de relações e pode ser representada graficamente por meio de um resumo, frase ou palavra.

Deste modo, partindo das respostas obtidas pelos participantes, foram desenvolvidas duas categorias de análise. Inicialmente, após a coleta de dados, as entrevistas foram transcritas e colocadas em quadros para uma melhor organização e visualização das informações, sendo um quadro com a transcrição literal e completa das entrevistas, outro com o destaque dos trechos mais significativos das entrevistas, e no terceiro quadro estes pontos foram correlacionados, destacando semelhanças e diferenças das respostas dadas pelos entrevistados. No texto 
referente aos Resultados e Discussão, foram feitos recortes das entrevistas, que foram citados literalmente, sendo analisados e discutidos a partir de fundamentos teóricos. Destarte, foi constituída a $1^{\underline{a}}$ categoria, que discutiu sobre a responsabilidade da escola frente à prevenção, suspeita ou identificação do abuso sexual infantil, sob o ponto de vista dos voluntários, bem como as práticas desta instituição a este respeito, e a $2^{\mathrm{a}}$ categoria abordou a formação e preparação dos professores quanto à prevenção, suspeita e identificação de possíveis vítimas, bem como suas ações e experiências com relação ao tema.

\section{RESULTADOS E DISCUSSÃO}

Os resultados obtidos nesta pesquisa serão apresentados e discutidos à luz de embasamentos teóricos e dos relatos dos professores entrevistados, a fim de conhecer e refletir sobre o posicionamento destes com relação a suspeita e identificação do abuso sexual frente a seus alunos, bem como a posição desses profissionais quanto a prevenção no contexto escolar.

\subsection{CATEGORIA 1 - E A ESCOLA? O QUE TEM A VER COM ISSO?}

Nesta categoria empenhou-se em discutir sobre a responsabilidade da escola frente à prevenção, suspeita ou identificação do abuso sexual infantil, de acordo com olhar dos professores entrevistados, bem como as práticas desta instituição a este respeito. Falar sobre o posicionamento da escola quanto ao tema aqui discutido, é falar também dos educadores e vice-versa, pois ao se discutir sobre o posicionamento de docentes quanto à problemática frente a seus alunos, como apresenta o título desta pesquisa, discute-se também sobre a escola como um todo, já que os professores são parte desta instituição e suas práticas dizem não somente sobre cada profissional em si, mas também sobre a instituição como um todo. Quando questionados sobre a existência ou não de alguma responsabilidade da escola frente à temática houve opiniões divergentes. Maria e Pedro afirmaram que a escola tem uma responsabilidade: 
Sim, sim. Eu vejo assim: nós professores somos orientados a primeiramente sermos discretos, se nós percebermos já uma mudança do comportamento da criança [...] daí a gente deve se aproximar, né, ficar mais atento com o olhar; e depois ver se tem alguma coisa errada, e se for o caso chamar pra perguntar, e daí comunicar a direção, pra que a direção tome os passos pra comunicar Conselho Tutelar, fazer a denúncia, se for necessário - (Maria).

Sim, a escola... orientação, informação, tudo aquilo que a escola puder, assim, dar, né, um apoio, né, porque a gente não está aqui simplesmente pra passar um conteúdo, a gente também tá pra formar pessoas, né - (Pedro).

Já a professora Gleice, disse que a escola não tem condições de assumir tal responsabilidade:

A escola não tem como fazer isso. Como eu disse pra você, se a menina chegar e falar pra você assim, ó: "Meu padrasto tá abusando". O quê que a gente tem que fazer? Chamar mãe, chamar pai, chama todo mundo, entendeu? Colocar a família a par do assunto, e a família tomar uma providência. Porque a gente, se você for lá fazer um BO [...] por fim isso acaba mal pra você, é capaz de eles reverterem a família, falar assim que é você que abusa dela, você que tinha alguma intenção ruim, entendeu? Então a gente não fica com a responsabilidade. O que a gente vê, não tem como a gente provar $[\ldots]-$ (Gleice).

Gleice deixa claro que, para ela, a escola não possui responsabilidade alguma, a não ser a de avisar a família sobre o assunto e esperar que esta tome alguma providência. Além disso, falou de um receio de envolver-se em uma situação do gênero, de modo a fazer uma denúncia e ser acusada de ser a própria abusadora. Ainda, falou sobre não tomar uma providência porque não tem como provar que, de fato, o abuso sexual tenha ocorrido, argumento este que se assemelha ao de Noemi que, diferente de Gleice, não disse que a escola não tem responsabilidade quanto ao tema, entretanto, afirmou que a escola só pode se responsabilizar caso tenha certeza de que o abuso sexual tenha acontecido:

Ah, eu acho que a escola tem que se responsabilizar quando ela tem certeza, né [...] o máximo que a gente pode fazer é uma conversa com essa criança, mas não sei se a gente pode ir muito afundo no sentindo assim de... deixar essa criança mal ou você ficar falando perto de alguém, então eu acho muito difícil na relação professor-aluno no ensino fundamental onde as classes são lotadas você perceber e conversar, por isso eu acho que seria preciso na escola ter psicólogos, né, que assim, a professora presta uma atenção, mas ela encaminha pra alguém conversar, porque pra gente é muito mais 
complicado [...] então eu acho muito difícil abordar esse problema com a criança na escola - (Noemi).

Outro ponto marcante na fala de Noemi foi quando ela disse que o máximo que poderia fazer seria ter uma conversa com a criança que apresenta suspeita ou que relata uma situação de abuso sexual, e logo em seguida disse que é difícil perceber e conversar com um aluno sobre o assunto, devido à superlotação das salas de aula, afirmando que este seria um trabalho difícil para um professor e expõe que acha necessário que a escola tenha à sua disposição um profissional de psicologia para que este tome providências com relação à criança. $O$ preocupante na fala de Noemi é que ela relatou sobre a escola ter responsabilidade apenas caso tenha certeza da mencionada violência; em seguida disse que o que pode ser feito é uma conversa com o aluno sobre o problema, mas, logo depois, relatou que é difícil para o professor ter uma conversa deste tipo com o aluno ou perceber algum indício de abuso sexual frente a eles. Então, se a escola apenas terá responsabilidade se o abuso for confirmado, logo, para Gleice, a escola não tem o compromisso de atuar quanto à prevenção e suspeita do abuso sexual infantil. Ainda, como ela terá responsabilidade mediante a certeza do fato consumado se o professor na sala de aula não consegue ao menos conversar com seus alunos sobre isto? Sabe-se que, de fato, muitas escolas públicas enfrentam o problema da superlotação em sala de aula, como mostram os participantes da pesquisa de Mariano e Muniz (2006), que analisou a relação entre saúde mental e o trabalho de professoras da rede pública do município de João Pessoa - PB. Nesta pesquisa, as docentes também falaram sobre o assunto afirmando que a superlotação de alunos nas salas de aula interfere no processo ensino-aprendizagem e dificulta que o professor consiga oferecer atenção direcionada a todos (MARIANO; MUNIZ, 2006, p.83).

Entretanto, diante da realidade, é necessário que a equipe escolar pense em estratégias de como lidar com a situação fazendo o possível para que seus alunos não fiquem desamparados nesse sentido, já que uma das atribuições da escola é promover a proteção da criança e do adolescente frente à violação de seus direitos (INOUE; RISTUM, 2008). 
A postura apresentada por Noemi limita a responsabilidade da escola tanto quanto a de Gleice, que disse que o que a escola pode fazer é conversar com a família, para que esta tome as atitudes cabíveis, mesmo que a criança fale declaradamente à escola que ela foi abusada sexualmente. A professora expôs um posicionamento de evitar tomar outras providências por medo de ser prejudicada de alguma forma, e ela deixa isto claro em sua fala: "Um professor que vai querer denunciar, você acaba perdendo o seu cargo, porque você não tem provas, você precisa de provas".

O posicionamento de Gleice se assemelha ao de Noemi, já que esta disse que o que tem a fazer é falar com a família, mas depois afirmou que também é difícil fazê-lo e também acabar sendo prejudicada, caso esta família de volte contra a professora: "Mas tem gente que já de cara, já não admite, você já vê que vai fazer barraco, "Onde já se viu você falar assim", "Você não me conhece", então, o que você vai fazer? É a criança falando, como é que você vai falar?". Então, se por receio de ser prejudicada, a escola não fizer uma denúncia e não comunicar a família, qual seria o posicionamento da escola? Quando Gleice disse: "O que é que você vai falar?", entende-se que ela está afirmando que não tem o que falar. Ou seja, para ela, a escola não tem o que fazer nesses casos e, portanto, declarou: "[...] a gente não fica com a responsabilidade".

De fato, pode suceder que a família, além de negar que o abuso sexual possa ter acontecido, ainda se levante contra a escola por esta tomar providências sobre o ocorrido, entretanto, a instituição pode sim tomar uma atitude preservando a integridade dos educadores por meio da denúncia ao Conselho tutelar, buscando neste órgão também orientações de como proceder nestes casos, ou até mesmo fazendo uma denúncia anônima a depender da situação por meio do disque 100, em que é garantido o sigilo sobre a fonte das informações (BRASIL, s/d). Este método garante que o denunciante não sofra qualquer dano e permite que todos os casos sejam denunciados.

Sendo assim, a fala de Gleice quando afirmou que "A escola não tem como fazer isto", evidencia o fato de que há uma contradição entre o que a legislação prevê e o 
que acontece na prática, considerando, por exemplo, o Parágrafo único do art. 70-B do ECA, que prevê:

São igualmente responsáveis pela comunicação de que trata este artigo, as pessoas encarregadas, por razão de cargo, função, ofício, ministério, profissão ou ocupação, do cuidado, assistência ou guarda de crianças e adolescentes, punível, na forma deste Estatuto, o injustificado retardamento ou omissão, culposos ou dolosos (BRASIL, 1990).

Sendo assim, a não denúncia é tão grave quanto a própria prática do abuso sexual infantil, já que, quem não denuncia, acaba sendo conivente com a situação. Além disso, a escola é uma instituição que já carrega em si a responsabilidade de prestar assistência a seus alunos, e a equipe escolar precisa ter clareza disso. Então, podese dizer que é inadequada a postura de uma escola que tente não se envolver com casos como de violência sexual, já que é uma instituição importante para o trabalho contra a violação dos direitos de crianças e adolescentes, como mostram Inoue e Ristum (2008) e é parte de fundamental de uma rede, como discutido na revisão teórica deste trabalho, não apenas para a formação de identidade e socialização do aluno, mas também no que se refere à proteção da criança.

Esta discussão proposta pelas autoras está próxima da fala do professor Pedro, que apresentou a perspectiva de que a escola tem sim responsabilidade quanto ao abuso sexual frente a seus alunos, e afirma que tudo o que a escola puder, ela deve fazer em defesa deles, já que a escola não tem o compromisso apenas de fazer com que seus alunos aprendam o conteúdo das disciplinas e, diferente da fala de Noemi e de Gleice, Pedro foi coerente com a discussão de Inoue e Ristum (2008) apesar de seu discurso ter sido breve e de não ter pontuando como, então, a escola poderia agir para cumprir com esta responsabilidade. Já a professora Maria, que também foi defensora da ideia de que a escola é sim responsável frente o abuso sexual infantil, falou mais sobre o que ela poderia fazer diante disto referindo-se a um processo de identificação de um caso de abuso sexual e disse que os professores são orientados a serem discretos, prestarem atenção nas mudanças de comportamento dos alunos, aproximar-se deles, atentar-se ao olhar dos estudantes, verificar se algo está errado 
e, se for o caso, perguntar ao aluno sobre o assunto e então comunicar a direção da escola para que esta faça a denúncia se for necessário.

De fato, os pontos abordados por Maria são importantes já que ser discreto quando houver uma suspeita é imprescindível para evitar que a criança ou adolescente seja exposta diante de seus colegas e, além disso, a discrição e o cuidado ao falar com o aluno sobre esse assunto são necessários para que ele não seja violentado mais uma vez, revivendo a situação da violência toda vez que tiver que repetir sobre o ocorrido. Outro ponto interessante mencionado pela professora é a importância de se prestar atenção nas mudanças de comportamentos dos alunos, e isto não somente para a identificação do abuso sexual infantil, mas também para outras possíveis situações que a criança pode estar enfrentando, considerando a possibilidade de seus direitos estarem sendo violados de várias outras formas.

Ainda, como Maria apontou, é importante que haja uma aproximação do aluno, e ter uma conversa com ele também é indispensável para o processo de identificação do abuso sexual e, é interessante que esse movimento aconteça para além de como disse Maria: "[...] Se for o caso chamar pra perguntar [...]"; isto porque a conversa com o aluno não precisa acontecer diante de uma suspeita muito evidente de abuso sexual, e sim até mesmo em pequenas circunstâncias em que o professor puder desconfiar de que possa estar havendo algo diferente com as crianças e/ou adolescentes. Aliás, os pequenos indícios que as vítimas de abuso sexual infantil (bem como de qualquer tipo de violência ou negligência) manifestarem, devem ser levados em consideração e podem ser determinantes para o processo de identificação e, assim, para a tomada de providências em prol da interrupção de abusos sexuais aos quais a criança ou adolescente pode estar sendo submetidos, como também o afastamento da criança da convivência de seu agressor, que além de tudo, pode estar causando um sofrimento psicológico, fazendo com que a vítima permaneça sob ameaças.

Considerando que o ECA prevê em seu art. 131, em que claramente determina que "O Conselho Tutelar é órgão permanente e autônomo, não jurisdicional, encarregado 
pela sociedade de zelar pelo cumprimento dos direitos da criança e do adolescente, definidos nesta Lei" (BRASIL, 1990), o Conselho Tutelar tem um dever de agir em zelo aos direitos das crianças e adolescentes. Assim, como afirma Quadros (2014), cabe ao Conselho Tutelar avaliar a situação em atendimento a essas crianças e adolescentes e decidir se há a necessidade de medidas de proteção, e quais as ações que melhor preservam seus direitos assegurados na lei. Sendo assim, caso a escola entre em contato com a mencionada instituição, o Conselho Tutelar deve tomar as medidas cabíveis em relação ao caso, podendo até, como previsto no art. 136, parágrafo único do ECA, se entender que seja necessário, afastar a criança ou adolescente do convívio familiar, devendo comunicar ao Ministério Público prestando-Ihe informações sobre a razão de tal entendimento e atitudes tomadas para a orientação, suporte e promoção social da família (BRASIL, 1990).

Deste modo, o empenho da escola em identificar e denunciar casos de abuso sexual pode mudar a história de crianças e adolescentes. Como previsto no ECA, a escola, enquanto uma das instituições sociais fundamentais no desenvolvimento de crianças e adolescentes, tem o dever de se responsabilizar pelo cumprimento da proteção integral desse público, considerando que o compromisso social e a atuação sobre crianças e adolescentes vítimas de qualquer tipo de violência é uma obrigação legal das instituições educativas. A lei é clara em determinar que em casos de suspeita ou confirmação de violência contra a criança ou adolescente sejam obrigatoriamente notificados ao Conselho Tutelar, sem excluir outras providências legais (BRASIL, 1990). Diante de mais que um compromisso, uma obrigação da escola de notificar o Conselho Tutelar em casos de suspeita ou confirmação de abuso sexual infantil, apenas um dos professores entrevistados mencionaram sobre a denúncia a este órgão, neste caso, a entrevistada Maria.

Outro aspecto importante a ser discutido é que, a professora Gleice, várias vezes durante a entrevista, repetiu como argumento para a não atitude da escola com relação ao abuso sexual infantil que: "O que a gente vê, não tem como a gente provar [...]", entretanto, é importante que se saiba que não cabe à escola e nem ao docente averiguar e confirmar se houve ou não o abuso sexual com determinado (a) 
aluno (a). A obrigação da escola, segundo a lei, é denunciar não somente casos confirmados, mas também os de suspeita de abuso sexual. Muitos desses delitos não são denunciados pelo mesmo receio de Gleice, de que não se pode provar, ou ainda porque não se tem certeza do ocorrido, e em função disso muitas crianças não são amparadas e libertadas da situação do abuso e de outras violências diante de seu agressor. Porém, a suspeita já é um motivo importantíssimo para uma denúncia e, caso o abuso não seja confirmado, a fato de o Conselho Tutelar ter sido notificado não ocasionará mal algum à criança ou à escola, bem como a seus profissionais.

Não somente o Conselho Tutelar, mas a Delegacia Especializada ou Ministério Público possuem competência para acolher as denúncias feitas e solucionar os casos encaminhados. Além disso, como apontam Pereira e Conceição (2014, p.142), "Nos casos de riscos à integridade física da escola ou do professor, as Secretarias Estaduais ou Municipais de Educação devem oferecer proteção e suporte à comunidade escolar". Assim, o receio que Gleice apresentou em sua fala: "[...] por fim isso acaba mal pra você [...]", referindo-se ao próprio professor ser prejudicado ao fazer uma denúncia de abuso sexual, tendo como vítima um de seus alunos (as), poderia não ser um empecilho para a atuação da escola frente a esta responsabilidade, se buscasse apoio nesses meios de proteção à comunidade escolar, ou se ao menos tivesse conhecimento sobre isto.

É importante salientar que o acompanhamento das denúncias feitas pelas escolas bem como por outros setores das Secretarias Estaduais ou Municipais de Educação oferece aos professores a garantia de que os casos notificados não serão esquecidos (PEREIRA; CONCEIÇÃO, 2014, p.137). Infelizmente a escola tem atuado pouco com relação às denúncias de abuso sexual infantil, como mostra a já mencionada pesquisa de Habigzang et al. (2005, p. 344),

A violência sexual foi denunciada pela mãe da vítima em $37,6 \%$ dos casos, pela própria vítima em $29 \%$ dos casos, por outros parentes, em $15,1 \%$, e, por instituições, tais como, escola, hospital e departamento de polícia em $6,5 \%$ dos casos. 
Esta pesquisa é apenas um recorte, mas denuncia a situação macro de dificuldade que instituições como as escolas apresentam para denunciar situações de suspeita ou confirmação de abuso sexual infantil aos órgãos de proteção, apesar de a denúncia ser um procedimento determinado por lei.

Um aspecto importante com relação à fala dos professores é que nenhum deles mencionou sobre a responsabilidade da escola frente à prevenção do abuso sexual infantil, tendo alguns deles perpassado de certa forma apenas pelo processo de suspeita e de identificação da violência. A entrevistada Maria, apesar de ter sido a que mais mencionou sobre a atuação em relação ao abuso sexual infantil em sua escola, também não apresentou nenhuma fala sobre a responsabilidade da instituição quanto à tão importante prevenção.

Quando questionados se a escola em que trabalham pratica alguma ação de prevenção contra o abuso sexual infantil, os professores entrevistados apresentaram respostas semelhantes e argumentos discrepantes. Maria afirmou:

Olha, eu sei que tem um programa [...] que trabalha bastante a sexualidade das crianças, que trabalha mais nas aulas de ciências [...]. Então, falava muito sobre sexo, mas não exatamente sobre o abuso, entendeu? [...] Nas aulas de português trata-se de tudo, porque o nosso foco é a comunicação. Eu posso discutir qualquer assunto; se vem a tona a gente toca no assunto, dá pra gente conversar, e se o material traz a gente traz e debate, né. Mas assim, um trabalho específico eu acredito que nunca participei - (Maria).

Pode-se observar na fala da professora que o tema da sexualidade provavelmente é trabalhado com os alunos nas aulas de ciências, o que é comum da própria disciplina, já que, dentre outras coisas, estuda o corpo humano. Entende-se que estas discussões são de extrema importância para informar e conscientizar os alunos quanto ao seu corpo e sexualidade. Todavia, Maria relatou que o tema do abuso sexual especificamente não é explorado com os alunos da escola. Ela relatou ainda que em suas aulas de português tem liberdade para discutir sobre qualquer assunto, mas que apenas que o faz "se vem à tona" (sic.) ou "se o material traz" (sic.), ou seja, não há uma programação que garanta que haja um trabalho de prevenção contra o abuso sexual diante dos alunos desta escola. 
Já Noemi teve um discurso enfático ao afirmar que a escola não possui práticas de prevenção contra a violência em questão, mas, como Maria mencionou sobre a possibilidade de algo sobre a sexualidade ser trabalhado em disciplinas como de ciências ou Biologia:

Nunca trabalhei em nenhuma escola que praticasse nada disso; a única... os únicos projetos que conheço dentro da escola é sobre drogas, né, ah.... doenças sexualmente transmissíveis, mas abuso sexual infantil nunca foi falado. Um tema abordado, assim, que eu tenha visto palestras nas escolas, nunca; que eu tenha visto projetos pra trabalhar, nunca. A não ser que tenha, assim, com o professor de ciências, de biologia, né que talvez trabalhe alguma coisa com esse tema, mas eu nunca vi, assim, uma coisa que seja interdisciplinar, não - (Noemi).

Como já mencionado, as discussões sobre sexo e o corpo humano são indispensáveis no contexto escolar junto às disciplinas específicas do assunto, mas não é suficiente para se obter a prevenção do abuso sexual. É grave a fala de Noemi quando disse que nunca foi falado sobre abuso sexual infantil com os alunos da escola e que jamais houve palestras ou projetos sobre este tema. Isto é, segundo Noemi, não há movimentação alguma sobre a problemática frente aos alunos, que ficam absolutamente destituídos até mesmo de pequenas informações que poderiam Ihes ser importantes para sua autoproteção.

Gleice também afirmou que a escola não possui práticas de prevenção contra o abuso sexual infantil, porém, seu argumento diferenciou-se do dos outros participantes:

\begin{abstract}
Não, imagina! Porque eles são tudo evangélicos, menina, você vai abrir a boca, já vai falar que você está induzindo os filhos deles a alguma coisa (risos). [...] geralmente até a questão da sexualidade, esses temas assim que tem um projeto do governo que ele tenta conter a gravidez na adolescência porque isso é custo pra ele, né. Aí ele tenta conter a gravidez, aí ele manda o projeto todo pronto, o professor de biologia e alguma outra área mais próxima que trabalha isso. Mas esses temas não são trabalhados na escola - (Gleice).
\end{abstract}

Gleice, além de afirmar que a escola não intervém com relação à prevenção do abuso sexual infantil, ainda coloca instituição como se fosse impossibilitada de tratar de temas como estes frente a seus alunos. De fato, assuntos que se referem à 
sexualidade ainda são censurados e como aqui já discutido, vistos como um tabu em pleno século XXI. Entretanto, há a necessidade de se pensar em estratégias para lidar com a situação. Além disso, pode ocorrer que, não somente as famílias, mas até mesmo os educadores se esquivem do assunto. Beiras; Tagliamento e Toneli (2005) na pesquisa em que realizaram uma capacitação com educadores do Fórum Maciço do Morro da Cruz, em Florianópolis/SC, no intuito de estimular a reflexão sobre questões que se referem à sexualidade e ao gênero nas escolas, verificaram que o trabalho sobre sexualidade nessas instituições ainda é coberto de polêmica devido à diversidade de visões, valores e crenças de alunos, pais, professores e diretores com relação à temática. Segundo os autores, as dificuldades começam com a própria sexualidade dos educadores, que se sentem pouco à vontade para estabelecer uma conversa franca com os alunos sobre determinados temas, dificultando o enfrentamento de circunstâncias inesperadas que surgem constantemente no contexto escolar.

Deste modo, há ainda que se quebrar tabus não somente dos pais dos alunos, que são a quem Gleice se referiu em sua fala, mas também de todos os envolvidos no contexto escolar, inclusive da própria equipe escolar, para que esta tenha potencialmente condições de trabalhar com os alunos estes assuntos mais delicados como o abuso sexual infantil.

Sobre as práticas da escola quanto à prevenção do abuso sexual infantil, o professor Pedro declarou que, como é um professor relativamente novo na instituição, não consegue responder tal pergunta com propriedade, mas mencionou sobre uma figura importante no contexto escolar; trata-se do denominado Professor Mediador:

Olha, eu tô aqui há pouco tempo, então, essa pergunta eu não consigo responder. Sinceramente... e como... não faz nem um ano que eu tô aqui, então eu não sei se já foi feito, mas eu lembro que até o ano passado tinha professora mediadora e isso ajudava bastante ao meu ver, né, porque ela sempre dava o atendimento para os alunos, daí se algum professor queria conversar a respeito de algum problema, algum conflito, alguma coisa, sobre aquele determinado aluno ela sempre tava pronta, né, e também a direção ficava a par de tudo isso, né, a direção da escola, então acho que a 
professora mediadora, que havia esse projeto na rede estadual é uma coisa que ajudava, né - (Pedro).

A criação da função do Professor Mediador Escolar e Comunitário (PMEC) se deu pela implementação do Sistema de Proteção nas escolas públicas do Estado de São Paulo. Trata-se de uma iniciativa que reúne ações interdependentes e correlacionadas que visam a proteção de todos os atores da comunidade escolar, incluídos pais, alunos, professores e funcionários, seja em relação aos atos de indisciplina e conflitos mais graves que atinjam os diversos segmentos escolares, seja a respeito do cometimento de crimes, assim como qualquer outro fator de vulnerabilidade a que a escola possa estar exposta (LEANDRO, 2014). A Resolução SE 19/2010 instituiu oficialmente o Sistema de Proteção Escolar (SPE) na rede do estado de São Paulo, sendo alterada em 20 de janeiro de 2012 pela Resolução SE no 07, que prevê:

Artigo 10 - O artigo $7^{0}$ da Resolução SE nํㅜ 19, de 12 de fevereiro de 2010, passa a vigorar com a seguinte redação: "Art. $7^{\circ}$ - Na implementação das ações específicas do Sistema de Proteção Escolar, a escola poderá contar com até 2 (dois) docentes para atuarem como Professor Mediador Escolar e Comunitário, cujas atribuições consistem, precipuamente, em: I - adotar práticas de mediação de conflitos no ambiente escolar e apoiar o desenvolvimento de ações e programas de Justiça Restaurativa; II - orientar os pais dos alunos, ou responsáveis, sobre o papel da família no processo educativo; III - analisar os fatores de vulnerabilidade e de risco a que possam estar expostos os alunos; IV - orientar a família, ou responsáveis, quanto à procura de serviços de proteção social; V - identificar e sugerir atividades pedagógicas complementares, a serem realizadas pelos alunos fora do período letivo; VI - orientar e apoiar os alunos na prática de seus estudos" (NR) (SÃO PAULO, 2012).

Sendo assim, o Professor Mediador Escolar e Comunitário deve apresentar vantagens na comunicação interpessoal da comunidade escolar, proporcionando uma melhora no clima escolar e contribuindo para a formação integral do aluno. "Preservando e se antecipando para prevenir as relações entre os profissionais e os alunos, entre os alunos que divergem entre si, conscientizando da necessidade de disciplina consciente, como o autocuidado" (LEANDRO, 2014, p.92). 
Destarte, o PMEC pode atuar nas escolas auxiliando, dentre outras coisas, nos trabalhos de prevenção, suspeita e identificação do abuso sexual infantil. Entretanto, como já aqui afirmado, sabe-se que a realidade se diverge do que é previsto por lei em muitas instituições públicas e privadas, e a escola é uma delas. Como mostrou o Professor Pedro em sua fala, não há mais nesta escola a atuação de um PMEC e, além disso, partindo do discurso dos outros professores entrevistados, que atuam a mais tempo nesta instituição especificamente, nem em outros momentos houve um trabalho específico quanto ao Abuso Sexual Infantil e nenhum outro participante mencionou alguma ação por parte de professores mediadores nesta escola.

Diante do que foi exposto pelos professores participantes desta pesquisa, pôde-se perceber que a escola permanece desamparada de ações de prevenção contra o abuso sexual infantil, bem como apresenta uma dificuldade em estratégias para lidar com a suspeita e identificação de tal violência. Além de que, a própria consciência sobre a responsabilidade da instituição quanto ao tema não está clara a toda a equipe escolar, tomando por base os apontamentos dos entrevistados. Assim, percebe-se que institucionalmente esta escola apresenta lacunas importantes quanto ao tema; propõe-se agora, nesta discussão, refletir sobre o docente especificamente, sob o olhar dos próprios entrevistados.

\subsection{CATEGORIA 2 - E EU COM ISSO? O PREPARO E AS AÇÕES DOS PROFESSORES.}

a última categoria de análise visa discutir sobre a preparação dos professores quanto à identificação de possíveis vítimas, bem como sobre suas ações e experiências com relação ao abuso sexual infantil frente a seus alunos. quando questionados consideram-se preparados para quanto à identificação de possíveis vítimas de abuso sexual infantil, os professores entrevistados deixaram claro que não se sentem preparados para esta ação frente a seus alunos. maria declarou que:

Não. Eu acho que eu preciso de mais informações. O que eu tenho é a sensibilidade natural de ser humano. Porque é assim, o que eu pego de orientação, se você desconfiar de algo, nos comunique. Eu me baseio mais

RC: 96446

Disponível em:

https://www.nucleodoconhecimento.com.br/psicologia/posicionamento-de-docentes 
naquilo que o meu conhecimento de mundo, a minha percepção, mas não acho que eu sou preparada não - (Maria).

Como Maria, Gleice também mencionou a vivência como algo que a ajuda no processo de identificação do abuso sexual infantil:

Eu de curso, eu não tenho nenhum curso, né, mas a gente, assim, por vivência, né, assim, por comportamento dos alunos, aí pelo que eles costumam falar [...], né, porque eles contam, né. Aí você acaba associando um pouco, né a situação em especial, né, de repente pode estar acontecendo, né - (Gleice).

Além disso, Gleice se ocupou em falar sobre o aluno vítima de abuso sexual pela perspectiva da aprendizagem de conteúdos teóricos, ou pela dificuldade que a criança apresenta neste processo de aprendizagem, dizendo que tenta encontrar meios de fazer tal criança produzir boas notas, devido a uma exigência do governo que, segundo ela, não se preocupa com a situação emocional do aluno, a não ser que ele seja "laudado" (sic.):

[...] o aluno não aprende nada, um aluno que não socializa, e o governo manda prova querendo nota dele. Então, eu preciso identificar, né, o que será que tá acontecendo pra ter uma conversa ali com ele pra ver se eu consigo fazer ele produzir alguma coisa... ai que maldade! (risos). O problema dele mesmo, que é resolver toda a vida dele eu não posso, eu tenho que resolver o problema do governo, que ele quer nota, ele quer que ele saiba todos os conteúdos, mas aí você fala assim: "Ah, mas a pessoa tá com algum problema, né, emocional, ele deve tá passando por alguma coisa". Você tem como provar? (risos) Não, né. [...] Mas como ele não é laudado o Estado não reconhece esse aluno como DI. E aí exige que ele tenha o mesmo aprendizado, o mesmo, né, desempenho que os outros, e aí? - (Gleice).

Gleice retomou com sua fala, discursos já apresentados nesta discussão, de que o professor não tem como provar o que vê, e outra vez isto ocupa um lugar de empecilhos de ações contra o abuso sexual frente aos alunos. Nesse sentido, professora é ainda mais enfática em dizer que sua palavra não tem valor algum, e ainda, fala sobre seu posicionamento quanto ao que ensina a seus alunos:

Quer dizer, a minha palavra não serve pra nada na escola, entendeu? Palavra de professor, da direção não serve pra nada. Você pode morrer de ver as coisas aqui, mas não serve pra nada. Até que a família tome uma atitude, vai lá fazer o laudo dele, vai lá... não serve pra nada, o que eu falo, o que eu vejo 
não serve pra nada. Altamente frustrante essa profissão (risos); a gente diria que é um lixo, porque eu ensino um monte de coisa assim, que eu fico pensando: "Gente isso daqui tá tão em desuso, é tão inútil isso, tão, assim, fora dos cabo" (risos). É tanto lixo pra mente deles e o que eu precisava mesmo ensinar, que seria bom pra eles a gente não pode, a gente esbarra na família, esbarra na sociedade, esbarra lá na delegacia, se você tem como provar, esbarra na.... Se você vai encaminhar ao médico "É, então, mas quem te falou isso?" eu vou falar que fui eu? (risos). Então é um lixo, simplesmente um lixo, você vê e não pode fazer nada, entendeu? - (Gleice).

Além de Gleice, Noemi também retoma a ideia de que diante de uma providência tomada pelo professor, a criança pode negar que o abuso tenha acontecido, e este não ter como provar o fato, e acabe sendo prejudicado. Ela alega que não se acha preparada para a identificação de possíveis vítimas:

Eu acho que não [...] como que eu vou abordar essa criança, entendeu? O quê que ela vai falar pra mim, e aí eu vou responder pra quem? Eu vou procurar a direção, e a direção vai procurar o Conselho Tutelar, e de repente na hora essa criança nega, ou os pais ou a pessoa que abusou vai ficar em cima dessa criança, ou até mesmo encima de mim; eu acho uma situação muito complicada. [...] Então, eu penso que eu não estou preparada pra isso, porque, de repente essa criança chega, e eu tô percebendo, eu posso até comunicar a direção pra chamar o Conselho Tutelar, mas eu ir conversar, eu ir atrás dessa criança, eu ir atrás da família, não - (Noemi).

Já o professor Pedro apresentou a perspectiva de que a direção da escola é que estaria mais preparada para identificação do abuso sexual frente a seus alunos, já que cuida não somente de uma turma, mas de todas:

Não, não me considero preparado porque eu não sei de a pouca experiência que eu ainda tenho, né, em sala de aula, mas isso não vem ao caso, também, acredito eu. Mas eu acho que pela minha formação, que eu acredito que outros profissionais, né, que estão às vezes até numa hierarquia maior que a minha dentro da escola, tenha outras visões e outras decisões, né, pra se tomar perante isso, devido à função da pessoa, então, são outras experiências, né, que a hierarquia tem... a hierarquia maior, né, gestão escolar, né, que é diretora, vice, elas têm um outro jeito de lidar, uma outra visão, já passaram por mais coisas do que a gente que é professor, não só porque elas tão numa hierarquia maior, mas é porque esse caso da... do profissionalismo delas, né de se resolver as coisas e os conflitos nas escolas, né, porque elas pegam o conflito de forma geral, a gente só pega numa sala, elas não, elas têm que abraçar a escola inteira, assim, praticamente, né, porque tá dentro da responsabilidade da direção dela. - (Pedro). 
Diante da ideia que Pedro exprime que a direção estaria mais capacitada para exercer o papel de identificar casos de suspeita de abuso sexual frente aos alunos, pode-se pensar sobre como isso seria possível se não fosse via um trabalho que contasse com toda a equipe escolar. Cardoso e Menezes (2009) discorrem sobre a importância de a qualificação e sensibilização de agentes estatais acerca do abuso se dar de forma irrestrita e constante, permeando o trabalho tanto de profissionais envolvidos diretamente com as crianças e adolescentes, como também dos que têm contatos eventuais como, por exemplo, funcionários administrativos. Assim, entende-se que no contexto escolar, esta preparação deve ser feita com todos os funcionários da instituição, isto é, não somente responsabilizar a direção da escola quanto à problemática, tão pouco responsabilizar somente o professor por isto. É necessário que toda a equipe escolar esteja atenta à identificação de possíveis vítimas, sendo desde diretores, coordenadores, professores, até funcionários que trabalham na parte administrativa, na cozinha, na higienização do ambiente escolar etc.

Pedro mencionou também a respeito de sua pouca experiência enquanto um docente que possui menos tempo nesta área em relação aos outros professores da escola em que trabalha e disse não se considerar preparado para a identificação do abuso sexual infantil. Apesar de dizer que "isso não vem ao caso" (sic.), ao falar sobre sua pouca experiência, ele abordou em seu discurso sobre a experiência (ou a falta dela). Gleice também apresentou durante a entrevista esta perspectiva da "vivência" (sic.) como algo que possa colaborar para o processo de identificação do abuso sexual diante dos alunos, ao dizer que não tem respaldo de algum curso que a preparasse para esta ação. Pode-se dizer que Maria também abordou sobre esses meios que utiliza para atuar frente à problemática, sendo, em suas palavras, "a sensibilidade natural de ser humano", "meu conhecimento de mundo" (sic.).

Isto posto, é possível pensar sobre vários aspectos que perpassam o trabalho dos professores frente à identificação do abuso sexual. Não se pode desconsiderar que a experiência, as habilidades que cada pessoa possui para perceber determinadas situações, independentemente de ser educador ou não, pode colaborar para o 
processo de identificação do abuso sexual infantil, entretanto, isto é pouco para tornar uma pessoa devidamente preparada para o combate contra a mencionada violência. Libâneo (2002) discute sobre o trabalho do professor enquanto uma ação prática e possuidora de dois sentidos, o de ser um fazer ético orientado por objetivos (envolvendo, então, a reflexão) e o de ser uma ação instrumental adequada a situações; a reflexão sobre a prática não é suficiente para resolver tudo, e a experiência refletida também não resolve tudo. Deste modo, "são necessárias estratégias, procedimentos, modos de fazer, além de uma sólida cultura geral, que ajudam a melhor realizar seu trabalho e melhorar a capacidade reflexiva sobre o que e o como mudar" (LIBÂNEO, 2002, p.76).

Nesse sentido, pode-se dizer que há a necessidade de preparação e reflexão dos docentes frente a várias problemáticas no contexto escolar. Gleice, além de mencionar sobre a vivência como única base para suas ações frente à identificação do abuso sexual infantil, ela apresenta em sua fala outro aspecto, que é a aprendizagem do aluno que passou pela violência. É bem verdade que, de fato, a criança vítima de abuso sexual pode ter diferentes problemas escolares, como denotam Papalia, Olds e Feldman (2006), e é importante que o professor trabalhe para tentar dar a este aluno o apoio necessário diante de suas dificuldades.

Outro ponto retomado pela professora é sobre seu despreparo quanto à identificação abuso sexual infantil sob o seguinte argumento: "Você tem como provar?". Em outro momento ela disse que a palavra do professor não tem valor: "Palavra de professor, da direção não serve pra nada. Você pode morrer de ver as coisas aqui, mas não serve pra nada". Noemi também retomou o fato de que não tem meios de provar que o abuso tenha ocorrido ou que a criança tenha alegado isto; ela apresentou novamente um receio de ser prejudicada ao relatar suas suspeitas, quando disse: "Eu vou procurar a direção, e a direção vai procurar o Conselho Tutelar, e de repente na hora essa criança nega, ou os pais ou a pessoa que abusou vai ficar em cima dessa criança, ou até mesmo em cima de mim". Como já discutido na categoria de análise anterior, existem meios de se tomar providências 
acerca do abuso sexual infantil sem que o professor seja prejudicado e até mesmo, sem que ele seja identificado.

Entende-se mais uma vez que há a necessidade de os professores estarem mais informados quanto ao assunto; pode-se pensar também que muitas vezes, esses profissionais acabam por não tomarem atitudes quanto ao tema devido a essa falta de informação, mas também pela ausência de discussões em equipe, para que esta seja fortalecida tanto em conhecimento como em estratégias para lidar com diferentes situações frente a seus alunos.

Outro aspecto importante a ser pontuado é sobre a desmotivação em que muitos professores têm se encontrado. Isso pode ser ilustrado com a fala de Gleice, em que ela afirmou: "[...] Gente, isso daqui tá tão em desuso, é tão inútil isso, tão, assim, fora dos cabo" (risos). É tanto lixo pra mente deles e o que eu precisava mesmo ensinar, que seria bom pra eles a gente não pode [...]". Sabe-se que o professor está inserido em uma realidade adversa, que é acompanhada de baixa remuneração, reconhecimento e qualificação profissional, o que pode gerar sentimentos de desânimo, cansaço, apatia, desesperança e passividade entre os professores, que se sentem se sem recurso para enfrentar a todas estas demandas e pressões (PATIAS; BLANCO; ABAID, 2009).

Deste modo, o olhar do professor perpassa por estes fatores e em muitos casos acaba tendo um resultado ruim em sua prática profissional. O termo "lixo", usado por Gleice pode dizer um pouco sobre esta situação vivida pelos professores da educação brasileira. Logicamente não se pode aqui diagnosticar e dizer sobre os motivos de a professora ter apresentado tal fala, entretanto é possível refletir por meio dela sobre situações em que os professores têm se encontrado e sobre a perspectiva que eles acabam tendo em relação ao seu trabalho.

Gleice queixa-se de que tem que responder ao Governo com boas notas de seus alunos, tendo que ensinar a eles os conteúdos previstos, e que por isso não consegue ensinar o que acha importante; isto referindo-se à falta de ações de sua 
parte contra o abuso sexual frente a seus alunos. Entende-se que o professor precisa seguir um conteúdo programático instituído para cada período que os alunos cursam em sua fase escolar; entretanto, sabe-se que é preciso que o professor tenha a capacidade de promover estratégias para lidar com situações para além do conteúdo teórico, já que, como discutido aqui, a escola tem o dever de formar sujeitos em diferentes âmbitos que envolvem seu desenvolvimento, bem como é responsável por atuar em proteção a seus alunos.

O Art. 277 da Constituição da República Federativa do Brasil de 1988, que é a lei que rege o país, prevê que:

É dever da família, da sociedade e do Estado assegurar à criança, ao adolescente e ao jovem, com absoluta prioridade, o direito à vida, à saúde, à alimentação, à educação, ao lazer, à profissionalização, à cultura, à dignidade, ao respeito, à liberdade e à convivência familiar e comunitária, além de colocá-los a salvo de toda forma de negligência, discriminação, exploração, violência, crueldade e opressão.

Assim sendo, todos, sem exceção, devem estar comprometidos em proporcionar à criança e ao adolescente o que é previsto nesta lei, já que neste artigo ela abarca não somente a família e o Estado, mas a toda a sociedade como responsáveis sobre o cumprimento desta lei. Além disso, como aqui já discutido, a escola enquanto o papel importante que exerce na vida de seus alunos tem um compromisso ainda mais significativo para o cumprimento desta lei e os professores como agentes importantes para com seus alunos, não podem negligenciar e deixar de mover ações que promovam movimentos que caminhem em direção ao cumprimento desta lei.

Com isto, pode-se pensar: o professor deve ensinar ao aluno o conteúdo previsto pela esfera governamental, mas, por outro lado, sem deixar de cumprir com suas responsabilidades quanto ao cumprimento das leis frente à criança e ao adolescente em meio a seu trabalho. Portanto, percebe-se mais uma vez que há a falta de informação, preparação e estratégia aos professores, que acabam por não saberem como lidar com a situação, e muitos nem ao menos têm ciência de suas responsabilidades com crianças e adolescentes, o que acaba resultando em 
desproteção dos alunos em muitos aspectos, bem como quanto ao abuso sexual infantil.

Sobre a formação dos profissionais da educação em relação ao abuso sexual infantil, alguns dos participantes entrevistados avaliaram que é leve e precária:

Muito leve, muito leve. Eu acho que precisaria tomar cuidados, principalmente hoje em dia. [...] Acho que deveria ter mais informações; eu sinto essa carência enquanto professora - (Maria).

Ah, eu acho precária ainda, né. [...]A formação hoje a gente não tem essa orientação, né [...] - (Noemi).

Outros professores afirmaram que não tiveram formação alguma a este respeito:

Não tem. O governo até diz que tem, manda uns cursos pra você ler lá (risos) se você entender, entendeu, se não entender (risos)... eu nem sei se tem, eu nunca fiz um curso desse, não lembro de ter visto nenhuma orientação desse tipo - (Gleice).

Sinceramente a gente... não fomos preparados, não fomos, assim, instruídos, né[...] acho que falta, falta... algum projeto, alguma coisa que [...] capacite professores e... né, que dê pelo menos o básico pra que a gente possa passar isso daí a diante - (Pedro).

Esta falta de preparação mencionada pelos entrevistados é uma realidade que fere gravemente o que é previsto no ECA:

Art. 70-B. As entidades, públicas e privadas, que atuem nas áreas a que se refere 0 art. 71, dentre outras, devem contar, em seus quadros, com pessoas capacitadas a reconhecer e comunicar ao Conselho Tutelar suspeitas ou casos de maus-tratos praticados contra crianças e adolescentes (BRASIL, 1990).

Destarte, a lei prevê que os profissionais das áreas da informação, cultura, lazer, diversões, entre outros, precisam estar capacitados a reconhecer e a denunciar possíveis casos de violação do direito da criança e do adolescente, e isto engloba violências como ao abuso sexual (BRASIL, 1990).

Diante da formação defasada em preparar profissionais para o enfrentamento da violência, e da necessidade da formação docente para tal, Pereira e Conceição 
(2014) apontam que têm surgidos algumas propostas. Uma delas é a criação do Guia Escolar em 2003, criado em ação conjunta entre a Secretaria de Educação, Alfabetização e Diversidade (Secad) e a Secretaria Especial dos Direitos Humanos (SEDH), visando auxiliar como um instrumento aos educadores com relação à identificação de sinais de abuso e exploração sexual contra crianças e adolescentes.

O projeto Escola que Protege é outra proposta, desenvolvida pelo Ministério da Educação em 2004 por meio da Secad com o propósito de viabilizar ações de cunho educativo e preparativo para o enfrentamento da violência contra crianças e adolescentes. Em 2006 a formação de professores e demais profissionais do campo da educação para que atuem como atores importantes na garantia dos direitos da criança e do adolescente foi determinada como prioridade básica. A formação se deu pela Universidade Federal de Santa Catarina mediante um curso de educação a distância, seguido de uma etapa presencial realizada em todas as regiões do Brasil por universidades estaduais e federais (PEREIRA; CONCEIÇÃO, 2014).

Pereira e Conceição (2014) afirmam ainda que o curso foi denominado "Formação de educadores: subsídios para efetuar no enfrentamento à violência contra crianças e adolescentes". É possível perceber que a preocupação com a construção de propostas é evidente principalmente em projetos de formação continuada. Entretanto, projetos relacionados à violência contra crianças e adolescentes na formação inicial dos professores não se encontram com facilidade, ainda menos propostas que não possuam uma perspectiva imediatista para a solução desta problemática.

Entende-se que a busca pela informação pode ser constituída como uma forma de se preparar na atuação contra o abuso sexual infantil, já que, tendo conhecimento sobre 0 assunto, a possibilidade de trabalhos de prevenção e suspeita de casos aumenta, podendo inclusive, a partir de então, solicitar ajuda a equipamentos da rede de diferentes serviços, sobre como agir caso haja dúvidas de acordo com cada situação. Há uma literatura vasta sobre o assunto como, por exemplo, o caderno da Secad "Proteger para Educar: a escola articulada com as redes de proteção de 
crianças e adolescentes", que visa compartilhar conhecimentos com profissionais de educação sobre diferentes formas de violência os contextos sociais que promovem as ações agressivas e sobre situações de risco (SECAD, 2007). Ter conhecimento sobre 0 assunto ajuda 0 profissional a minimamente não deixar alunos permanecerem despercebidos diante da violência sofrida.

Brino e Willians (2005), como já apresentado neste trabalho, afirmam que a capacitação de professores pertence ao nível primário de prevenção do abuso sexual infantil, que tem por objetivo eliminar ou reduzir os fatores sociais, ambientais e culturais que sejam propícios para os atos de agressão. Neste nível também estão as promoções de ações junto à população de risco, promovendo a educação de crianças sobre os riscos do abuso sexual, já que, como apontam Santos e Ippolito (2009) educação sexual é a melhor maneira de prevenção, pois um programa de educação continuada é capaz de preparar as crianças e adolescentes a se defenderem desta violência.

Outro meio de prevenção citado pelos autores é a inclusão social da criança tida como "diferente", ou rejeitadas pelos grupos. "Atrás da subjugação da criança ao abuso sexual sofrido em casa ou na vizinhança ou seu silêncio diante dele, normalmente existe uma busca de aceitação e afeto de um ente querido" (SANTOS; IPPOLITO, 2009, p.128). Assim, muitas das crianças acabam sendo vítimas de abuso sexual possuindo baixo nível de estima própria, geralmente crescendo isoladamente na própria casa e na comunidade em que vive, e não tendo orientações sexuais fundamentais.

Visando a prevenção, Santos e Ippolito (2009) sugerem às escolas que estas promovam a sensibilização dos familiares responsáveis pela educação das crianças e dos adolescentes; manterem um relacionamento de confiança com a criança; dedicarem tempo a ela, e ouvir abertamente o que a criança tem a dizer, não banalizando sua fala e; construírem uma rede de social de suporte entre os familiares no trabalho de proteger a criança. 
Nesse sentido, capacitar crianças e mães a reconhecerem sinais de que o abuso sexual esteja ocorrendo, pode ser uma ação que efetivamente interrompa a ocorrência de tal violência. Esta intervenção direcionada à criança trabalharia sobre o reconhecimento de sinais de aproximação de um agressor, bem como sobre o reconhecimento de comportamentos sexuais inadequados. Às mães, a ação envolveria reconhecimento de comportamentos indicadores do abuso sucedido. Tratando-se de ações de detecção de crianças e adolescentes em situação de risco, rompendo com os atos violentos ou suas repetições, intervindo em casos já confirmados e trabalhando na prevenção de sequelas possíveis, esta perspectiva se enquadra na prevenção secundária ou até terciária (BRINO; WILLIANS 2005).

Muitas outras ações podem ser realizadas contra o abuso sexual infantil pelos professores e por toda a equipe escolar. Entretanto, há a dependência de que estes profissionais busquem respaldo em uma formação continuada, já que, de modo geral, as questões que se referem à sexualidade humana são quase ausentes do currículo de quase todos os cursos em nosso país. Do mesmo modo, pouco se fala sobre violência durante a graduação de nossos profissionais. Associando-se a ausência de clareza nos conceitos com uma ignorância quase total sobre a legislação e das atribuições de diferentes instituições, se terá como resultado, profissionais despreparados para o enfrentamento dos casos reais que se manifestam, temerosos em se posicionar frente a estes e receosos de que o encaminhamento de uma suspeita possa resultar em alguma inconveniência legal para este profissional (LERNER, 2000).

Isto tudo pode ser visto na prática e ilustrado pela fala dos professores entrevistados quando disseram sobre suas ações quanto à prevenção do abuso sexual infantil: "Não, nunca fiz nenhum projeto, a única coisa mesmo é a observação e a aproximação do aluno" - (Maria). Resposta esta que se repete em semelhança na fala de Noemi: "Não, eu como professora de Arte nunca abordei nada nesse tema, tá?"; Maria, Noemi e Pedro afirmaram com clareza de que não nunca promoveram ações de prevenção contra o abuso sexual frente a seus alunos. Gleice também falou sobre sua atuação: "Eles perguntam, a gente responde, mas assim, eu ficar 
falando assim, não, né; eu respondo pro curioso [...]", porém, este não pode ser considerado um método de prevenção, já que responder às perguntas que (e se) surgirem é muito pouco e, além disso, as crianças que não fizerem perguntas a este respeito à professora, permanecerão sem informação alguma sobre o tema.

Partindo do pressuposto de que o abuso sexual infantil é mais comum do que é exposto à sociedade, pode-se pensar que muitas crianças e adolescentes que foram violentados sem que houvesse quem identificasse o ocorrido e movesse meios para a interrupção do abuso. Essas vítimas em sua maioria passaram ou passam por um período escolar e já foram alunos de vários professores, que não fizeram intervenções sobre isto. A pouca quantidade de casos evidentes ou denunciados em relação ao real número de vítimas dá a impressão de que existem poucos casos de abuso sexual. Os participantes desta pesquisa falaram sobre suas experiências com algum aluno em que houve suspeita ou identificação do abuso sexual infantil, e Noemi afirmou que nunca se deparou com um aluno nessas condições.

A professora Maria e o professor Pedro afirmaram que já tiveram um aluno que sofreu abuso sexual infantil, mas que não foram eles quem constataram e sim a escola já havia sido informada sobre o caso: "Sim, já tive mas já era coisa constatada. Eu percebia a diferença na aluna, no caso, e aí eu fui perguntar, e aí falaram que ela sofria" - (Maria); "Olha, eu já fiquei sabendo... não foi nessa escola, foi numa outra escola... eu.. de um menino que foi abusado pelo padrasto, e realmente ele tinha problemas, né, em sala de aula" - (Pedro). Ambos os professores afirmaram que perceberam que os alunos em questão tinham uma postura diferente em sala de aula, porém essa percepção veio apenas após eles serem informados sobre o abuso. Este é mais um aspecto que incita novamente a reflexão sobre a necessidade de capacitação para a identificação de possíveis vítimas de abuso sexual.

A professora Gleice afirmou que teve uma aluna que contava várias coisas a ela: "[...] xavecavam a menina né, sabe assim, coisas assim, né, envolvia essa menina 
de diversas formas, eu não sei não se eles não praticavam até sexo com ela [...]". Gleice disse também sobre sua atitude em relação a isto:

Ah, eu comentei, né, com professores no ATPC [...] aí todo mundo optou por falar que o comportamento dela era ruim, que tinha que falar com a mãe, que não sei o que, passou pra coordenação. Passou pra coordenação, morreu o assunto (risos) - (Gleice).

O caso apresentado por Gleice se trata de uma situação em que a adolescente contou a ela sobre fatos que envolviam o abuso sexual. Esta, por sua vez, comunicou o acontecido com a equipe escolar e, pelo que relatou, nada foi feito por conta do comportamento de indisciplina da aluna na escola. Vê-se aí o quão é importante que o professor tenha domínio de informações a respeito de tal violência, para que, em vez de estigmatizar o aluno, entender que o posicionamento dele pode ser oriundo de uma situação como esta. A professora contou que não tomou outras providências e que só sabe que a aluna mencionada passou a se prostituir.

É preciso que providências sejam tomadas para que as crianças e adolescentes não mais sejam negligenciados. Como discutem Pereira e Conceição (2014, p.142), "A escola não é uma ilha". Ainda que se queira excluir a temática dos diferentes tipos de violência e deixá-lo ao lado de fora da escola, em meio à dificuldade de enfrentar situações que a envolvem, da falta de respaldo institucional e de meios de proteção para a própria escola, ainda que se queira negá-la, ela está presente na instituição e gera incômodo no cotidiano, especialmente da sala de aula, nas constituições das diferentes relações.

\section{CONCLUSÃO}

Este trabalho permitiu conhecer e discutir o posicionamento de professores com relação à prevenção, suspeita e identificação do abuso sexual infantil no contexto escolar, que foi o objetivo deste trabalho, alcançado por meio de uma pesquisa de levantamento. Assim, pôde-se discutir sobre o olhar dos professores acerca da responsabilidade da escola frente ao abuso sexual infantil. 
Pode-se constatar que alguns docentes acreditam que a escola não tem responsabilidade quanto à mencionada violência, e outros entendem que esta instituição tem algum dever, mas estes demonstraram não ter conhecimento do quão responsável é pelo cuidado e proteção de crianças e adolescentes, apresentando em suas falas responsabilidades que seriam limitadas frente ao tema, e que estão muito aquém das obrigações da instituição previstas em lei. Deste modo, infelizmente é confirmada uma das hipóteses levantadas pela pesquisadora no projeto desta pesquisa que é o desconhecimento por parte dos professores sobre o impacto e sua responsabilidade quanto ao tema no contexto escolar.

Além disso identificou-se que há um evitamento da parte dos professores de envolverem-se em casos de abuso sexual frente a seus alunos, por receio de que acabe ocorrendo alguma inconveniência para estes profissionais. Então, discutiu-se sobre as diversas maneiras de a equipe escolar mover ações contra tal violência de modo a não serem prejudicados, e, além disso, discutiu-se como a não denúncia ser tão grave quanto o próprio abuso sexual infantil, conforme o art. 70-B do ECA (BRASIL, 1990). Alguns professores mencionaram que a família da criança é que tem que tomar providências quanto a isto, destituindo-se de toda a responsabilidade ou percebendo-se em um lugar de impotência afirmando que não há o que eles possam fazer quanto ao abuso sexual infantil. Isto também confirma outra hipótese levantada previamente neste trabalho, quando se observa que os professores acreditam que este assunto é de responsabilidade unicamente da família da criança, visto que seu foco está restrito ao processo de ensino-aprendizagem de conteúdos teóricos. Este posicionamento não foi comum a todos os entrevistados, porém manifestou-se em falas expostas por alguns participantes.

A análise mostrou ainda que alguns professores, em vários momentos, repetiram que deixam de tomar determinadas medidas quanto ao abuso sexual frente a seus alunos porque não tem como provar que o abuso ocorreu e nem mesmo que a criança ou adolescente tenha contado algo a eles. Deste modo, discutiu-se que não cabe à escola e nem ao professor constatar se houve ou não o abuso sexual com determinado aluno ou aluna. A obrigação da equipe escolar determinada pelo ECA é 
de notificar ao Conselho Tutelar (sem excluir outras providências legais) sobre não somente a confirmação, como também as suspeitas de crianças e/ou adolescentes que possam estar sofrendo ou ter sofrido abuso sexual.

Percebeu-se, também, nesta pesquisa, que a escola não possui nenhuma ação de prevenção quanto ao abuso sexual infantil. Alguns entrevistados disseram que pode ser que o tema seja trabalhado com os alunos durante aulas de ciências, que trata do corpo humano, mas afirmaram que não há a certeza de que este trabalho esteja sendo realizado. Portanto, nesta escola, segundo os entrevistados, não há nenhum projeto que fortaleça a equipe, preparando-a para que ela tenha condições de proporcionar algum respaldo para com os alunos em proteção contra o abuso sexual infantil.

Os professores entrevistados afirmaram também que nunca suspeitaram e identificaram uma criança ou adolescente que tenha sofrido abuso sexual, o que ocorreu foi que alguns professores tiveram contato com alunos dos quais a escola foi avisada que se tratavam de vítimas de tal violência; apenas uma professora afirmou que uma aluna contou a ela sobre ter sofrido abuso sexual, mas nunca houve uma ação desta professora para uma identificação; ela apenas soube porque a criança disse claramente a ela sobre o ocorrido. Sendo assim, pode-se pensar em outra hipótese levantada, que questionou se os professores acreditam que nunca estiveram frente a um caso de aluno vítima de abuso sexual, considerando que não têm conhecimento de como poderiam se atentar a este fenômeno. Esta hipótese é confirmada no sentido de que, de fato, os entrevistados afirmaram que Ihes faltam conhecimento para lidar com a problemática em questão, e confirma-se também na medida em que eles declararam que nunca identificaram um caso de abuso sexual entre seus alunos. O que não condiz com o resultando com relação a esta hipótese é que os professores afirmaram que já estiveram frente a um aluno vítima de abuso sexual, entretanto, isto ocorreu apenas porque Ihes foi informado previamente sobre o ocorrido com a criança. 
Considera-se que todos os professores relataram que não tiveram uma formação que desse a eles capacitação para o enfrentamento do abuso sexual infantil no contexto escolar. Viu-se que muitos professores têm apenas a experiência de vida como único instrumento para lidar com a temática frente a seus alunos, não obstante, discutiu-se que é preciso que o professor esteja capacitado a promover estratégias para lidar com situações como a violência sexual, já que, a escola tem o dever de formar sujeitos em diferentes âmbitos que envolvem seu desenvolvimento, bem como é responsável por atuar em proteção a seus alunos. Os professores disseram que, além de a formação não Ihes oferecer tal capacitação, não há uma formação continuada que eles tenham feito a este respeito; afirmaram que não sabem de nenhum programa de capacitação que estivera disponível a eles quanto ao abuso sexual infantil.

Isto posto, confirma-se a última hipótese levantada previamente, que questionou se professores não estão preparados para identificar, prevenir ou conduzir o processo frente a alunos vítimas de violência sexual na infância, visto que sua formação acadêmica não oferece conhecimento quanto ao tema, e os profissionais não buscaram conhecimento em uma formação continuada.

Ressalta-se que lidar com o abuso sexual infantil não é uma tarefa fácil. Por se tratar de uma violência que nem sempre deixa sequelas visíveis, é muito difícil de ser identificada, até mesmo para profissionais da psicologia, quanto mais para a equipe escolar. Por isso, é necessário que haja informação e capacitação dos profissionais do contexto escolar, para que eles possam corroborar para o combate a tão repudiável crime.

Uma possibilidade a esses professores, além de buscar por mais informações, seria uma roda de conversa em que se discutisse sobre o abuso sexual infantil e, com isso, cada professor poderia complementar as informações que seu colega possui sobre o tema, enriquecendo e fortalecendo a equipe para o enfretamento do problema frente a seus alunos. Para isto, um psicólogo escolar/educacional poderia trabalhar como mediador e até como promotor dessas reuniões com os educadores 
para se discutir o tema, auxiliando com seus saberes sobre grupos e instituições, desenvolvimento humano, aspectos psicológicos e sociais, dentre outros saberes e técnicas oriundas da psicologia para o auxílio e orientação da equipe escolar.

Neste aspecto, reflete-se sobre o papel da Psicologia diante destes cenários. Como explicam Cassins et al (2007), o psicólogo escolar/educacional pode trabalhar junto ao nível administrativo da escola, apoiando na elaboração do Projeto Político Pedagógico, na criação de projetos em conjunto com toda a equipe escolar, também fazendo o diagnóstico institucional, etc.; pode trabalhar com o corpo docente, dando apoio na definição de objetivos educacionais (métodos, conteúdos, e material didático), na promoção e/ou coordenação de atividades de desenvolvimento profissional, podendo fazer intervenção e acompanhamento para dificuldades individuais e/ou de grupo, orientação, entre outros; pode trabalhar junto ao corpo discente na elaboração, desenvolvimento e acompanhamento de projetos de prevenção à violência, pode fazer atendimento a situações de emergência psicológica que necessitem de intervenção imediata para posterior encaminhamento, pode atuar na coordenação e/ou participação em reuniões para discussão de casos de alunos em acompanhamento profissional externo, etc.; pode trabalhar também com a comunidade, dando orientações a pais e familiares, oferecendo palestras e atividades de esclarecimento, participando de atividades que auxiliem a escola a cumprir suas finalidades sociais, desenvolvimento de propostas que promovam o desenvolvimento de habilidades sociais significativas, entre outras ações.

Então, sabe-se que a Psicologia Escolar Educacional (PEE) pode auxiliar imensamente a equipe escolar quanto à prevenção, suspeita e identificação do abuso sexual infantil, como também em muitos outros aspectos. Todavia, sabe-se que na realidade poucas escolas podem contar com os serviços de tal profissional, por conta de não ser um profissional previsto, pela legislação brasileira, como fundamental no contexto escolar, o que acarreta a pouca contratação destes profissionais neste contexto. Assim, muitas escolas continuam enfraquecidas quanto 
a sua atuação para a proteção de crianças e adolescentes, bem como para a corroboração para que esses alunos tenham seus direitos garantidos.

É importante destacar que esta pesquisa vem corroborar com aquilo que já foi pesquisado por outras pessoas, tratando-se apenas de um recorte, que diz sobre os entrevistados, sobre a escola em que trabalham e sobre a realidade brasileira em diversos locais, ao passo que muitas outras pesquisas, como a de LERNER (2000), que apresentam resultados semelhantes ao encontrado neste trabalho. Por derradeiro, vale enfatizar a necessidade de aprofundamento nas pesquisas sobre 0 tema, tanto para corroborar a informação de profissionais e da população em geral, como também para contribuir com a instituição de novas estratégias de intervenção que fortaleçam a luta contra abuso sexual infantil.

\section{REFERÊNCIAS}

ADED et al. Abuso sexual em crianças e adolescentes: revisão de 100 anos de literatura. Revista de Psiquiatria Clínica 33 (4); 204-213, 2006. [online]. Disponível em: <http://www.hcnet.usp.br/ipq/revista/vol33/n4/204.html>. Acesso em: 27 de mai. de 2015.

ARAÚJO, M. de F. Violência e Abuso Sexual na Família. Psicologia em Estudo, Maringá, v. 7, n. 2, p. 3-11, jul./dez. 2002. [online]. Disponível em: <http://www.scielo.br/scielo.php?pid=S141373722002000200002\&script=sci_arttext> . Acesso em: 09 de set. de 2015.

AZAMBUJA, M. R. F. de. Violência sexual intrafamiliar: é possível proteger a criança? Revista Virtual Textos \& Contextos, no 5, nov. 2006. [online]. Disponível em: $<$ http://revistaseletronicas.pucrs.br/ojs/index.php/fass/article/view/1022>. Acesso em 09 de set. de 2015.

BEIRAS, A.; TAGLIAMENTO, G.; TONELI, M. J. F. Crenças, valores e visões: trabalhando as dificuldades relacionadas a sexualidade e gênero no contexto escolar. Aletheia, Canoas, n.21, p.69-78, jun. 2005. Disponível 
em:<http://pepsic.bvsalud.org/scielo.php?script=sci_arttext\&pid=S141303942005000 100007\&lng=pt\&nrm=iso $>$. Acesso em: 17 de set. de 2016 .

BRASIL. Ministério da Saúde. Notificação de maus-tratos contra crianças e adolescentes pelos profissionais de saúde. Secretaria de Assistência à Saúde. Série A. Normas e Manuais Técnicos; n. 167. Brasília-DF, 2002. [online]. Disponível em: $<$ http://bvsms.saude.gov.br/bvs/publicacoes/notificacao_maustratos_criancas_adoles centes.pdf>. Acesso em: 27 de mai. de 2015.

- Constituição (1988). Constituição da República Federativa do Brasil: promulgada em 5 de outubro de 1988. [online]. Disponível em: <http://www.planalto.gov.br/ccivil_03/Constituicao/Constituicao.htm>. Acesso em: 07 de out. de 2016.

. Estatuto da Criança e Adolescente. Lei 8.069, de 13 de julho de 1990. Brasília, 1990. [online]. Disponível em: <http://www.planalto.gov.br/ccivil_03/LEIS/L8069.htm>. Acesso em 09 de set. de 2015.

BRINO, R. F.; WILLIAMS, L. C. Capacitação do educador acerca do abuso sexual infantil. Interação em Psicologia, 7(02), p. 1-10, 2003b. [online]. Disponível em:<file:///C:/Users/Usuario/Downloads/3218-6348-1-PB\%20(1).pdf>. Acesso em 13 de abr. de 2016.

Prevenção primária, secundária e terciária do abuso sexual infantil. In:Sobre o comportamento e cognição- Expondo a variabilidade. Org. GUILHARDI, H. J.; AGUIRRE, N. C. de. p.174-181, 2005.

CASSINS, A. M. et al. Manual de psicologia escolar - educacional.CRP Curitiba: Gráfica e Editora Unificado, 2007. 45 p. [online]. Disponível em: <http://www.portal.crppr.org.br/download/157.pdf>. Acesso em: 14 de out. de 2016. 
CARDOSO, T. A. S.; MENEZES, R. E. Violência sexual e a ausência do estado: contexto de violências contra crianças e adolescentes. In: LAVARELLO, F. (Coord). Adefesa de crianças e adolescentes vítimas de violências sexuais. São Paulo: Cromosete, 2009, p. 159-166.

GERHARDT, T. E.; SILVEIRA, D. T. Métodos de pesquisa. Porto Alegre: Editora da UFRGS, 2009.

GIL. Métodos e técnicas de pesquisa social. 6. ed. São Paulo: Atlas, 2008.

HABIGZANG, L. F. et al. Abuso sexual infantil e dinâmica familiar: aspectos observados em processos jurídicos. Psicologia: Teoria e Pesquisa, Brasília, v. 21, n.3, p.341-348, 2005.2 Disponível em:<http://www.scielo.br/scielo.php?script=sci_arttext\&pid=S0102377220050003000 11\&lng=en\&nrm=iso>. Acesso em: 07 de set. de 2016.

INOUE, S. R. V.; RISTUM, M. Violência sexual: caracterização e análise de casos revelados na escola. Estudos de Psicologia (Campinas) [online]. 2008, vol.25, n.1, pp. 11-21. ISSN 1982-0275. Disponível em: <http://www.scielo.br/scielo.php?pid=S0103166X2008000100002\&script=sci_abstrac t\&tlng=pt>. Acesso em: 27 de mai. de 2015.

LEANDRO, S. A. Sistema de proteção escolar: é instrumento de proteção da cidadania? 2014.102 f. Tese (Mestrado) UniversidadeCidade de São Paulo UNICID, $2014 . \quad$ [online] Disponível em: <http://www.unicid.edu.br/wpcontent/uploads/2015/08/Disserta\%C3\%A7\%C3\%A3oSueli-AparecidaLeandro.pdf>. Acesso em: 18 de set. de 2016.

LERNER, T. Tratamento em situações de abuso sexual de crianças e adolescentes. In: Jornal da Rede Saúde, n.22, novembro de 2000. [online] Disponível em: <http://www.redesaude.org.br/home/conteudo/biblioteca/biblioteca/jornal/006.pdf>. Acesso em: 07 de out. de 2016. 
LIBÂNEO, J. C. Reflexividade e formação de professores: outra oscilação do pensamento pedagógico brasileiro? In. PIMENTA, S. G.; GHEDIN, E. (Orgs.). Professor reflexivo no Brasil: gênese e crítica de um conceito. São Paulo: Cortez, 2002. p. 53-80.

LONGO, M. Abuso sexual na infância: como lidar com isso? - Capacitando professores e pais para atuar em casos de abuso sexual na infância e adolescência. [S.I: s.n.], 2006, 80p.

MARIANO, M. do S. S.; MUNIZ, H. P. Trabalho docente e saúde: o caso dos professores da segunda fase do ensino fundamental. Estudos e pesquisas em psicologia, Rio de Janeiro , v. 6, n. 1, p. 76-88, jun. 2006 . Disponível em:<http://pepsic.bvsalud.org/scielo.php?script=sci_arttext\&pid=S180842812006000 100007\&lng=pt\&nrm=iso $>$. Acesso em: 10 de set. de 2016.

MARTINS, J. B. A atuação do psicólogo escolar: multirreferencialidade, implicação e escuta clínica. Psicologia em Estudos: Maringá [online]. 2003, vol.8, n.2, pp. 39-45. ISSN 1807-0329 Disponível em: <http://www.scielo.br/pdf/pe/v8n2/v8n2a04.pdf>. Acesso em 09 de set. de 2015.

PAPALIA, D.; OLDS, S.W.; FELDMAN, R. D. Desenvolvimento Humano. 8 ed.Porto Alegre: Artmed, 2006.

PATIAS, N. D.; BLANCO, H. M.; ABAID, J. L. W. Psicologia escolar: proposta de intervenção com professores. Cadernos de Psicopedagogia, São Paulo, v. 7, n. 13, p. 42-60, 2009. Disponível em $<$ http://pepsic.bvsalud.org/scielo.php?script=sci_arttext\&pid=S167610492009000100 003\&lng=pt\&nrm=iso $>$. Acesso em: 06 de out. de 2016.

PEREIRA, A. B. M.; CONCEIÇÃO, M. I. G. A escola e a proteção de crianças e adolescentes em situação de violência intrafamiliar. In: COSTA, L. F.; PENSO, M. A. CONCEIÇÃO, M. I. G. (Orgs.) Abordagem à família no contexto do conselho tutelar. 1 ed. São Paulo: Ágora, 2014, p.137-144. 
QUADROS, P. O. de. Breves fundamentos jurídicos para a atuação do Conselho Tutelar. In: COSTA, L. F.; PENSO, M. A. CONCEIÇÃO, M. I. G. (Orgs.) Abordagem à família no contexto do conselho tutelar. 1 ed. São Paulo: Ágora, 2014, p.25-39.

SANTOS. B. R. dos; IPPOLITO, R - Childhood Brasil. O papel da escola no enfrentamento da violência sexual. In: LAVARELLO, F. (Coord). A defesa de crianças e adolescentes vítimas de violências sexuais.São Paulo: Cromosete, 2009, p. $125-130$.

SÃO PAULO (Estado). Secretaria de Estado da Educação. Resolução SE no 07, de 19/01/2012. São Paulo, CENP/DRHU, 2012.

SECRETARIA DE EDUCAÇÃO CONTINUADA E DIVERSIDADE (SECAD). Caderno Cinco. Proteger para Educar: a escola articulada com as redes de proteção de crianças e adolescentes. Org.: HENRIQUES, R.; FIALHO, L.; CHAMUSCA, A. Brasília, 2007. [online] Disponível em: < http://pronacampo.mec.gov.br/images/pdf/bib_cad5_prot_ed_adoles.pdf>. Acesso em: 22 de out. de 2016.

SERAFIM, A. de P. et al. Dados demográficos, psicológicos e comportamentais de crianças e adolescentes vítimas de abuso sexual. Revista de Psiquiatria Clínica, São Paulo, v. 38, n. 4, p. 143-147, 2011. [online]. Disponível em: <http://www.scielo.br/scielo.php?script=sci_arttext\&pid=S010160832011000400006> Acesso em: 09 de set. de 2015.

UNICEF. Situação mundial da infância (edição especial): celebrando 20 anos da Convenção sobre os Direitos da Criança. UNICEF, 2009. [online] Disponível em: $<$ http://www.unicef.org/brazil/pt/sowc_20anosCDC.pdf>. Acesso em: 03de jun. de 2016.

VAGOSTELLO et al. Violência Doméstica e Escola: Um Estudo em Escolas Públicas de São Paulo. Paidéia, 2003, 13(26), 191-196. [online]. Disponível em: <http://www.scielo.br/pdf/paideia/v13n26/08.pdf>. Acesso em 09 de set. de 2015. 
WILLIAMS, L. C. A. Abuso sexual infantil. In: GUILHARDI, H. J.; AGUIRRE, N. C. (Orgs.). Sobre Comportamento e Cognição: Expondo a variabilidade. Santo André: ESETec, 2002, v.10, p.155-164.

\section{APÊNDICE - REFERÊNCIA NOTADE RODAPÉ}

3. Site UNICEF: <http://www.unicef.org/brazil/pt/activities_10790.htm>.

Enviado: Agosto, 2021.

Aprovado: Setembro, 2021. 